\title{
A Pediatric Case of Reversible Segmental Cerebral Vasoconstriction
}

\author{
Adam Kirton, John Diggle, William Hu, Elaine Wirrell
}

\begin{abstract}
Background: Reversible segmental cerebral vasoconstriction (RSCV) is a recognizable clinical and radiographic syndrome consisting of thunderclap headache with or without focal neurological symptoms combined with reversible segmental vasoconstriction of proximal cerebral blood vessels. Methods: We report a case of reversible segmental cerebral vasoconstriction in a child. Results: A healthy 13-year-old boy experienced the sudden onset of a severe, diffuse headache upon surfacing from a deep dive in a swimming pool. Severity was maximal at the onset and improved over several hours. The same headache recurred three times over the next four days and a low baseline headache persisted throughout. Vomiting occurred once and mild photo/osmophobia were reported but throbbing, aura, or autonomic symptoms were absent. Focal neurological signs or symptoms were absent and he denied previous history of headaches, medications, drugs, or trauma. Two normal CT scans were performed within hours of separate headaches. Cerebrospinal fluid study on day 5 was bloody with no xanthochromia. MRI/MRA/MRV of the brain and vasculitic work-up were normal. Cerebral angiography on day 6 demonstrated smooth narrowing of multiple proximal cerebral vessels including supraclinoid internal carotid artery (ICA), M1, and A1 on the right and M1 on the left. By ten days, the patient's headaches had resolved and repeat angiography was normal. Conclusion: RSCV should be considered in a child with thunderclap headache.
\end{abstract}

RÉSUMÉ: Un patient d'âge pédiatrique atteint d'une vasoconstriction cérébrale segmentaire réversible. Contexte: La vasoconstriction cérébrale segmentaire réversible (VCSR) est un syndrome clinique et radiologique reconnaissable, caractérisé par une céphalée en coup de tonnerre avec ou sans symptômes neurologiques focaux, associé à une vasoconstriction segmentaire réversible des vaisseaux sanguins cérébraux proximaux. Méthodes: Nous rapportons une observation de VCSR chez un enfant. Résultats: Un garçon de 13 ans, en bonne santé, a ressenti subitement une céphalée diffuse, sévère, en arrivant à la surface de l'eau après avoir effectué un plongeon en profondeur dans une piscine. La sévérité était maximale au début de la céphalée et a diminué dans les heures qui ont suivi. La même céphalée est réapparue trois fois au cours des quatre jours suivants sur un fond de céphalée persistante moins intense. Il a vomi une fois et il éprouvait une légère photo/osmophobie, sans douleur pulsatile aura ou symptômes au niveau du système nerveux autonome. Il n'avait pas de signes ou de symptômes neurologiques focaux et aucune histoire de céphalée antérieure ou de traumatisme, de prise de médicaments ou drogues. La tomodensitométrie effectuée dans les heures qui ont suivi deux épisodes différents de céphalée s'est avérée normale. Le liquide céphalo-rachidien prélevé au cinquième jour était sanglant, mais sans xanthochromie. L'IRM/ARM/VRM du cerveau et le bilan effectué pour déterminer s'il s'agissait d'une vasculite étaient normaux. L'angiographie cérébrale effectuée le sixième jour a montré un rétrécissement lisse de plusieurs vaisseaux cérébraux proximaux dont l'ACI, la M1 et l'A1 du côté droit et la M1 du côté gauche. La céphalée a disparu après dix jours et l'angiographie de contrôle était normale. Conclusion: La VCSR devrait faire partie du diagnostic différentiel de la céphalée en coup de tonnerre chez l'enfant.

Can. J. Neurol. Sci. 2006; 33: 250-253

Reversible segmental cerebral vasoconstriction (RSCV) is a recognizable clinico-radiographic syndrome consisting of thunderclap headache (TCH) with or without focal neurological symptoms combined with reversible, proximal, segmental cerebral vasoconstriction. Despite case reports over five decades, ${ }^{1-3}$ the eponymonic study of Call and Fleming et $\mathrm{al},{ }^{4}$ and improved recent recognition, $5,6 \mathrm{RSCV}$ remains poorly understood. The isolated occurrence and transient nature of RSCV may suggest an acquired etiology rather than classification as a primary headache disorder. Potential treatments for RSCV have been proposed but are unproven. ${ }^{7}$ Thunderclap Headache has an ever-expanding differential diagnosis ${ }^{8}$ but is rarely encountered in children and provides a challenge to physicians treating pediatric headache. We present a case of RSCV in a child and review issues of diagnosis, classification, mechanism, and treatment.

\section{Case Report}

A healthy 13-year-old boy was performing deep dives of 6-8 meters in a public swimming pool. Upon surfacing from his third consecutive dive, he experienced the sudden onset of a severe headache. An intense "squeezing pressure" was experienced in the occipital and vertex regions

From the Departments of Pediatrics, Divisions of Pediatric Neurology, (AK, EW), Clinical Neurosciences (JD, WH, EW), and Radiology (WH), Faculty of Medicine, University of Calgary, Calgary, AB, Canada

RECEIVED SEPTEMBER 6, 2005. ACCEPTED IN FINAL FORM JANUARY 23, 2006. Reprint requests to: Adam Kirton, Pediatric Stroke Program, Division of Neurology, Hospital for Sick Children, 555 University Ave., Toronto, Ontario, M5G 1X8, Canada. 
bilaterally. The pain reached maximal intensity (10/10) within 30 seconds $(\mathrm{TCH})$, remained there for another 20-30 minutes, then gradually improved over the following 4-6 hours to a persistent low intensity discomfort (2/10). There were no neurological symptoms prior to or during the event. He was assessed at a peripheral hospital and discharged after a normal head computed tomogram (CT).

The same TCH (10/10) recurred three times over the next four days superimposed on the constant, dull, low-intensity (2/10) headache. Mild vomiting, anorexia, photophobia and osmophobia were reported. The TCH was exacerbated by recumbency, exertion, and valsalva maneuvers. There was no previous history of headache. There were no recent illnesses or trauma, no medications, and he denied use of decongestants, sympathomimetics, serotonergics, recreational drugs, or alternative therapies.

The past medical, perinatal, and developmental histories were unremarkable. Family history revealed that one of six siblings had died from vertebral artery dissection after suffering a major trauma. There were three second degree relatives with migraine. The patient was first assessed by a pediatric neurologist on day 5 . Neurological and systemic examinations were normal and remained so over the next ten days.

Two normal CT scans were obtained within hours of separate headaches on days 1 and 5. An MRI including diffusion, angiography, and venography was normal on day 5. Routine bloodwork and a complete vasculitic work-up were normal. Cerebrospinal fluid (CSF) analysis on day 5 demonstrated no xanthochromia. However, $1250 \times 10^{9}$ red blood cells (RBC) per milliliter were counted in the first vial while $1375 \times 10^{9} \mathrm{RBC}$ were counted in the third vial. There were no white cells in either tube and both protein and glucose were normal. Due to an inability to explain the striking nature of the $\mathrm{TCH}$ and the persistent $\mathrm{RBC}$ in serial CSF samples, even without xanthochromia, formal cerbrovascular imaging was undertaken.

Conventional six vessel cerebral angiography on day 6 demonstrated smooth narrowing of multiple proximal cerebral vessels bilaterally (Figure 1). On the right side this included the proximal (A1) anterior cerebral artery (ACA) (Figure 1A), the supraclinoid internal carotid artery (ICA) (Figure 1B), and the proximal segment (M1) of the middle cerebral artery (MCA). On the left side, only the M1 segment was narrowed (Figure 1C). There were no other cerebrovascular anomalies.

After ten days (16 days from the original headache), repeat angiography showed essentially complete resolution of the previous abnormalities (Figure 1 D,E,F). The patient's severe headaches did not recur past day 7 and the mild constant headache resolved by day 9 . He has remained symptom free for 18 months since.

\section{Discussion}

Call et $\mathrm{al}^{4}$ described four adults with transient symptomatic vasospasm of bilateral, proximal cerebral arteries. Current descriptions of the RSCV syndrome are based on these and other small case series and reports ${ }^{1-3}$ and may be incomplete..$^{5,6}$

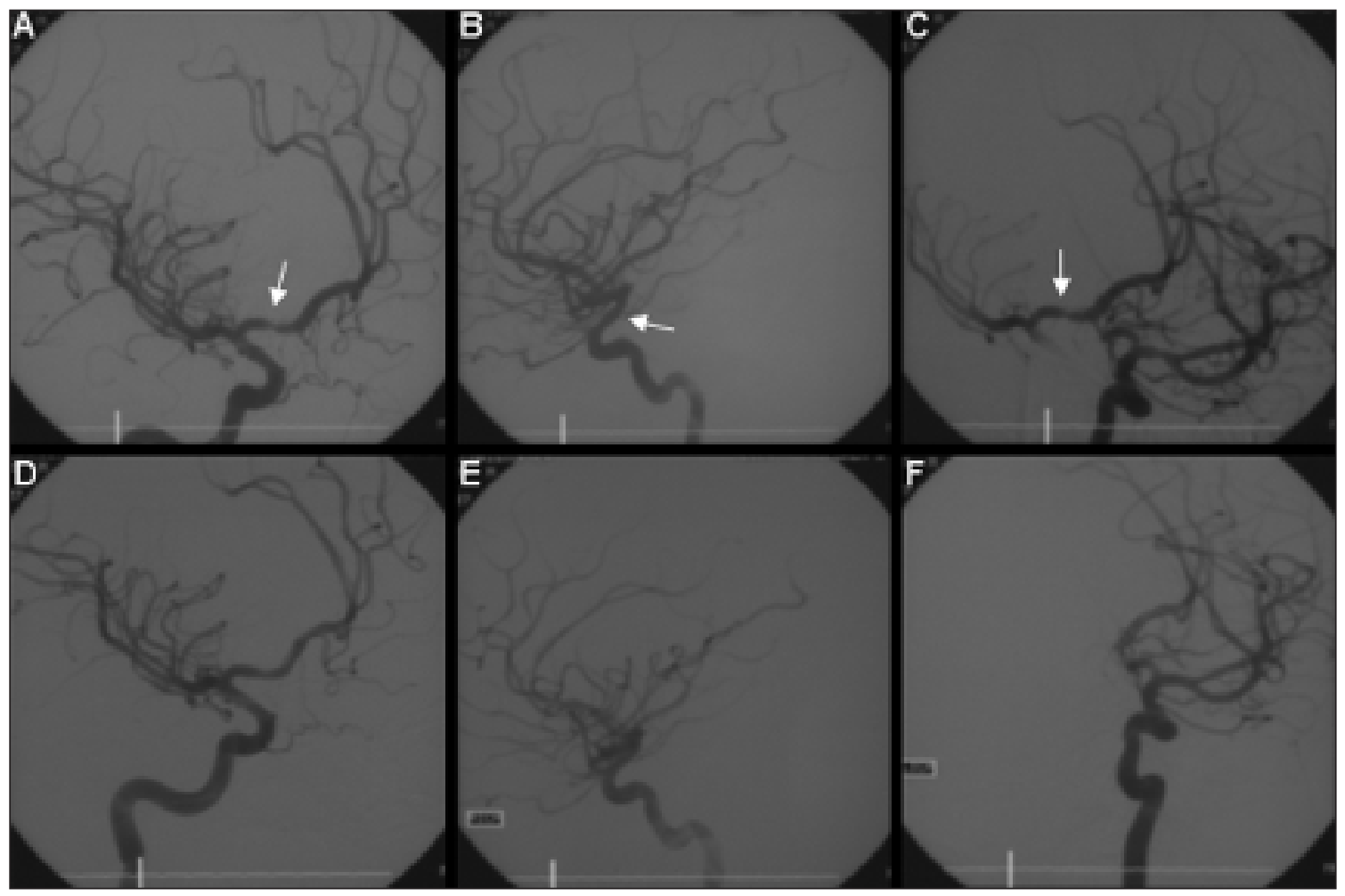

Figure: Cerebral angiography. Right ICA injection demonstrates smooth narrowing of A1 segment (A) and supraclinoid ICA (B). Left ICA injection shows similar vasospasm of left $M 1$ segment $(C)$. Lower images D, E, and F (identical projection to ' $C$ ' not available) demonstrate nearly complete resolution ten days later. 
Consistent features include an average age between 20 and 50 years and a predilection for females. A TCH mimics subarachnoid hemorrhage (SAH) with a sudden, explosive onset and features of nausea, vomiting, photophobia, and worsening with valsalva are common. Precipitants, including physical exertion or valsalva maneuvers, are described in $20-30 \%$ of cases. ${ }^{5,8}$ It is possible that such a mechanism, or perhaps a diving/surfacing-induced fluctuation in autonomic output, might have precipitated our patient's TCH. Focal neurological deficits or seizures may or may not occur and are assumed to be secondary to focal ischemia. Headache recurrence is usually limited to within the first ten days only. ${ }^{9}$ Recovery is the rule though significant morbidity from cerebral infarction and isolated fatalities have been reported. ${ }^{10,11}$

Reversible segmental cerebral vasoconstriction is not easily categorized in the recent International Headache Society's (IHS) classification system for headaches. ${ }^{12}$ Most similar is Primary Thunderclap Headache (PTH) which is classified as a primary headache (IHS section 4.6). ${ }^{12}$ Primary Thunderclap Headache includes TCH with additional criteria of: (1) severe head pain, (2) sudden onset with maximal intensity within the first minute and pain lasting between one hour and ten days, and (3) recurrence only during the first week. Also required are normal CSF analysis and neuroimaging and the exclusion of several diagnoses that would necessitate cerebral angiography. Given these similarities, some have suggested that RSCV be classified as a subtype of PTH, the only difference being the demonstration of multifocal segmental vasospasm on angiography. ${ }^{5,13}$

A second headache diagnosis with some similarity to RSCV is "Headache Attributed to Benign or Reversible Angiopathy of the CNS" (IHS section 6.7.3). ${ }^{7}$ Classified as a secondary headache disorder, the entity of post-partum angiopathy is often cited as an example. Criteria include: (1) diffuse, severe headache of abrupt or progressive onset with or without focal neurological deficits (FND) and/or seizures, (2) string of beads appearance on cerebral angiography, (3) one or both of headache developing simultaneously with focal neurological deficits/ seizures and headache leads to angiography and discovery of string of beads appearance, (4) both headache and FND resolve within two months. The obvious difference here is the angiographic pattern which would appear to support a different pathophysiology from RSCV.

The differential diagnosis for $\mathrm{TCH}$ has expanded to includes diverse etiologies such as venous sinus thrombosis, arterial dissection, vasculitis, hypertensive syndromes, intracranial hypotension, and others including several primary headache syndromes. ${ }^{8}$ Conditions associated with RSCV have also expanded and includes hypercalcemia, illicit drugs, trauma, chemotherapy, and pheochromocytoma. ${ }^{6}$ Subarachnoid hemorrhage remains the diagnosis until proven otherwise as $\mathrm{TCH}$ secondary to SAH can not be distinguished from other causes on a clinical basis. ${ }^{14}$ Therefore, all patients require careful investigation to exclude this list of possibilities, particularly children where aneurysmal SAH is rare.

The pathophysiology of cerebral vasospasm, including $\mathrm{RSCV}$, is poorly understood. The vessels affected in RSCV are heavily invested with sympathetic innervation and an abnormal discharge of sympathetic activity has been postulated. ${ }^{5}$ Such a neurohormonal mechanism may be supported by the association of RSCV with over-the-counter sympathomimetic agents ${ }^{15}$ and pheochromocytoma. ${ }^{1}$

The isolated, episodic nature of RSCV might suggest an acquired etiology and classification as a secondary, rather than primary, headache disorder. Most primary headaches feature chronic recurrence and, often, an inherited predisposition, neither of which are features of RSCV. Para-infectious regional vasculitidies, such as post-varicella angiopathy, ${ }^{16,17}$ are well described in children. An intriguing parallel analogy for an acquired etiology of RSCV is provided by a study conducted to screen for neurological manifestations of the Erve virus, ${ }^{18} \mathrm{a}$ bunyavirus discovered in the Erve Valley of France. In a cohort of 72 patients with non-hemorrhagic $\mathrm{TCH}, 166$ with viral encephalitis, and 205 healthy controls, ten (14\%) of the nonhemorrhagic $\mathrm{TCH}$ patients had serological evidence of recent Erve virus infection compared to only $1 \%$ of controls. On follow-up, no $\mathrm{TCH}$ patients had experienced recurrence though many had multiple headaches during the first week. Therefore, an acquired infection with a predilection for proximal cerebral vasculature and resultant vasospasm might explain some cases of RSCV. Evidence against a parainfectious vasculopathy includes the lack of clinical or CSF findings suggestive of infection in some studies of RSCV. ${ }^{6}$

An MR angiogram or transcranial Doppler ultrasound (TCD) can provide evidence of vasospasm, but their utility in RSCV has not been established. Therefore, serial cerebral angiography is required for definitive diagnosis. The risks of cerebral angiography are small and likely lesser still in children. Benefits of serial angiography include the exclusion of vascular malformation or aneurysm, including unruptured aneurysm which may be associated with $\mathrm{TCH} ., 13$ Therefore, a patient with unexplained $\mathrm{TCH}$ following complete investigation should undergo prompt cerebral angiography. Interval assessments with MRA or TCD might prove useful in monitoring of disease or timing of a second angiogram if correlations to the initial angiographic study can be established.

Enteric nimodipine, a voltage-gated calcium-channel blocker (CCB), appears to provide some protection against vasospasm following SAH. ${ }^{19} \mathrm{~A}$ benefit has been suggested in isolated cases of RSCV ${ }^{20}$ and a small series of patients with PTH, two of whom had documented vasospasm. ${ }^{8}$ Clinical trials required to establish benefit will be limited by the rarity of the condition and quick spontaneous resolution in many cases. Given the relatively good safety profile and theoretical extrapolation from post-SAH studies, use of nimodipine or other CCB in severe RSCV may be justified. The use of angioplasty has not been reported in RSCV. Supportive care includes management of seizures and cautious blood pressure control. For theoretical reasons, patients should probably avoid sympathomimetic medications including decongestants, appetite suppressants, and illicit drugs. Avoidance of vasoconstrictor headache medications (ergots, triptans) should also be stressed.

In summary, pediatric $\mathrm{TCH}$ carries a diverse and evolving differential diagnosis and RSCV should be considered in children with non-hemorrhagic TCH. 


\section{REFERENCES}

1. Armstrong FS, Hayes GJ. Segmental cerebral arterial constriction associated with pheochromocytoma. J Neurosurg. 1961;18:843-6.

2. Rousseaux P, Scherpereel B, Bernard MF, Guyot JF. Acute benign cerebral angiopathy - six cases. Presse Med. 1983;12:2163-8.

3. Serdaru M, Chiras J, Cujas M, Lhermitte F. Isolated benign cerebral vasculitis or migranous vasospasm. J Neurol Neurosurg Psychiatry. 1984:47:73-6.

4. Call GK, Fleming MC, Sealfon S, Levine H, Kistler JP, Fisher CM. Reversible cerebral segmental vasoconstriction. Stroke. 1988;19:1159-70.

5. Dodick DW, Brown RD, Britton JW, Huston J. Nonaneurysmal thunderclap headache with diffuse, multifocal, segmental, and reversible vasospasm. Cephalalgia. 1999;19:118-23.

6. Singhal AB. Cerebral vasoconstriction syndromes. Top Stroke Rehabil. 2004;11(2)1-6.

7. Lu SR, Liao YC, Fuh JL, Lirng JF, Wang SJ. Nimodipine for treatment of primary thunderclap headache. Neurology. 2004; 62(8):1414-6.

8. Dodick DW. Thunderclap headache. Headache. 2002;42:309-15.

9. Wijdicks EF, Kerkhoff H, van Gijn J. Long-term follow-up of 71 patients with thunderclap headache mimicking subarachnoid haemorrhage. Lancet. 1988;9(2):68-70.

10. Slivka A, Philbrook B. Clinical and angiographic features of thunderclap headache. Headache. 1995;35(1):1-6.

11. Singhal AB. Thunderclap headache, reversible cerebral arterial vasoconstriction, and unruptured aneurysms. J Neurol Neurosurg Psychiatry. 2002;73:96.

12. Headache Classification Subcommittee of the International Headache Society. International Classification of Headache Disorders, 2nd ed. Cephalalgia 2004; Supp1.
13. Boes CJ, Capobianco DJ, Cutrer M, Dodick D, Eross EJ, Swanson JW. Headache and other craniofacial pain. In: Neurology in Clinical Practice, Volume II: The neurological Disorders. Bradley WG, Daroff RB, Fenichel GM, Jankovic J, editors. Co. 2004, Elsevier, Philadelphia, PA. p. 2063.

14. Landtblom AM, Fridriksson S, Boivie J, Hillman J, Johansson G, Johansson I. Sudden onset headache: A prospective study of features, incidence, and causes. Cephalalgia. 2002;22(5):354-60.

15. Loewen AHS, Hudon ME, Hill MD. Thunderclap headache and reversible segmental cerebral vasoconstriction associated with the use of oxymetazoline nasal spray. CMAJ 2004;171(6):593-4.

16. Askalan R, Laughlin S, Mayank S, Chan A, MacGregor D, Andrew M, et al. Chickenpox and stroke in childhood: A study of frequency and causation. Stroke. 2001;32:1257-62.

17. Wirrell E, Hill M, Jadavji T, Kirton A, Barlow K. Stroke after varicella zoster vaccination: A possible causal association. J Pediatr. 2004; $145: 845-47$

18. Treib J, Dobler G, Haass A, von Blohn W, Strittmatter M, Pindur G, et al. Thunderclap headache caused by Erve virus? Neurology. 1998;50(2):509-11.

19. Rinkel GJ, Feigin VL, Algra A, van den Bergh WM, Vermeulen M, van Gijn J. Calcium antagonists for aneurysmal subarachnoid hemorrhage. Cochrane Database Syst Rev. 2002;(4):CD000277.

20. Nowak DA, Rodiek SO, Henneken, Zinner J, Schreiner R, Fuchs $\mathrm{HH}, \mathrm{S}$ et al. Reversible segmental cerebral vasoconstriction (Call-Fleming syndrome): Are calcium channel inhibitors a potential treatment option. Cephalagia. 2003;23(3):218-22. 